\title{
Simple Calculus of Resolving the Fiscal Policy Puzzle: The Role of Human Capital
}

\author{
Kazuki Hiraga \\ School of Political Science and Economics, Tokai University, Kanagawa, Japan \\ Email: khiraga581470@gmail.com
}

Received 25 September 2014; revised 26 October 2014; accepted 14 November 2014

Copyright (C 2014 by author and Scientific Research Publishing Inc.

This work is licensed under the Creative Commons Attribution International License (CC BY). http://creativecommons.org/licenses/by/4.0/

(c) †) Open Access

\begin{abstract}
This paper investigates how much externality of human capital a la on-the-job training resolves the fiscal policy puzzle that is consistent with the empirical evidences which obtain the positive response of consumption and wage to increase of fiscal spending in general equilibrium model.
\end{abstract}

\section{Keywords}

\section{Fiscal Policy Puzzle, Human Capital, General Equilibrium Model}

\section{Introduction}

The effect of fiscal policy reports different results between theory a lá dynamic general equilibrium, such as Barro and King (1984) [1], Baxter and King (1993) [2], and empirical one, such as Fatás and Mihov (2001) [3], Blanchard and Perotti (2002) [4] and Galí et al. (2007) [5]. These contradicted results are named in "Fiscal Policy Puzzle" that shows the controversial response of consumption and (real) wage to fiscal policy, which expands government expenditure. Concretely, the responses of consumption and wage decrease when the government expenditure increases in theoretical prediction, but empirical responses increase.

This paper induces the condition of resolving the "Fiscal Policy Puzzle" using static general equilibrium model with human capital which increases by on-the-job training. In the benchmark model of Barro and King (1984) [1], government spending is merely wasteful and causes a negative wealth effect, which decreases private consumption and increases labor supply, which decreases real wage as a result. On the other hand, we consider a possibility of positive comovement among labor supply and real wage to induce a positive production externality of human capital via on the job training which is advocated by literatures of human capital, such as Becker (2009) [6]. Although there are a lot of formations of human capital accumulation, we assume that labor supply accumulates human capital as on-the-job training. We obtain the results that the expanding government spending increases private consumption and real wage if the human capital externality is sufficiently large. 
The rest of this paper is organized as follow: Section 2 describes the model and Section 3 analyzes the model and obtains the conditions of positive responses on private consumption and wage. Section 4 provides conclusions.

\section{The Model}

We set the simple general equilibrium model with human capital derived by on-the-job (OJT) training.

\subsection{Households}

The (representative) household has the following life time preference and the budget constraint:

$$
\begin{gathered}
\ln C-\frac{N^{\lambda}}{\lambda} \\
\text { s.t. } C+T=w N+\pi,
\end{gathered}
$$

where $C$ is consumption, $N$ is labor supply, $T$ is lump-sum tax, $w$ is (real) wage $\pi$ is profit from the firm and $\lambda-1 \quad(>0)$ is the inverse of Frisch labor supply.

\subsection{Firm}

The firm maximizes its profit as follow:

$$
\pi=Y-w N
$$

where $Y$ is output (product) and production function is drawn as follow:

$$
Y=N^{\alpha} H^{\omega}
$$

where $\alpha \quad(\leqq 1)$ is the labor share (1- $\alpha$ means the profit share), $\omega$ is marginal production externality of human capital $H$.

\subsection{Human Capital}

In this model, we assume that human capital accumulates as labor supply increases like as an on-the-job-training. That is, worker (household) accumulates her ability as she increases labor supply. For simplicity, we assume the human capital is linear function on labor supply:

$$
H=\phi N
$$

where $\varphi$ is the coefficient of human capital accumulation.

\subsection{Government}

The government balances its budget; that is, the government levies lump-sum tax to finance government expenditure $G$ :

$$
G=T
$$

We assume that the initial government expenditure per output is constant; i.e. the ratio of government expenditure to output is $g\left(=\frac{G}{Y}\right)$.

\subsection{Market Clearing}

Combining household's budget constraint, profit function and government budget constraint, we obtain the market clearing condition as follow:

$$
C+G=Y
$$

\subsection{Equilibrium}

Solving the model, we obtain the equilibrium conditions as follows: 


$$
\begin{aligned}
& C=\alpha \phi^{\omega} N^{\alpha-\lambda+\omega} \\
& w=\alpha \phi^{\omega} N^{\alpha-1+\omega} \\
& C=(1-g) \phi^{\omega} N^{\alpha+\omega}
\end{aligned}
$$

\section{Analysis of the Model}

Using Equations (4), (5) and (6), we solve the model. The solutions are shown as:

$$
\begin{aligned}
& N=\left(\frac{\alpha}{1-g}\right)^{\frac{1}{\lambda}} \\
& C=\alpha^{\frac{1}{\lambda}} \phi^{\omega}(1-g)^{1-\frac{\alpha+\omega}{\lambda}} \\
& w=\alpha^{1+\frac{\alpha-1+\omega}{\lambda}} \phi^{\omega}(1-g)^{\frac{1-\alpha-\omega}{\lambda}}
\end{aligned}
$$

Using Equations (8) and (9), we obtain the following propositions with respect to the responses to expanding government spending (i.e. increasing $g$ ).

Proposition 1. The consumption increases when the government spending increases if $\lambda<\alpha+\omega$.

\section{Proof:}

Differentiating Equation (8) on $g$,

$$
\frac{\mathrm{d} C}{\mathrm{~d} g}=\left(1-\frac{\alpha+\omega}{\lambda}\right) \alpha^{\frac{1}{\lambda}} \phi^{\omega}(1-g)^{-\frac{\alpha+\omega}{\lambda}}
$$

If $\lambda<\alpha+\omega$, Equation (10) is positive. (Q.E.D)

Proposition 2. The (real) wage increases when the government spending increases if $1<\alpha+\omega$.

Proof:

Differentiating Equation (8) on $g$,

$$
\frac{\mathrm{d} w}{\mathrm{~d} g}=\frac{1-\alpha-\omega}{\lambda} \alpha^{1+\frac{\alpha-1+\omega}{\lambda}} \phi^{\omega}(1-g)^{\frac{1-\alpha-\omega}{\lambda}-1}
$$

If $1<\alpha+\omega$, Equation (11) is positive. (Q.E.D)

Proposition 1 represents the condition which the fiscal multiplier is larger than 1 . That is, response of consumption needs a sufficiently large multiplier shown in Equation (3). Resource constraint in Equation (3) explains that consumption increases when the increase in output is larger than government spending. Interpreting this proposition, marginal benefit of increasing labor supply $(\alpha+\omega)$ is sufficiently large and marginal cost $(\lambda)$ is relatively small, then labor supply increases sufficiently to increase consumption.

Proposition 2 means that the wage increases if the marginal productivity of labor is increasing relationship with respect to labor supply. That is, if production externality $(\omega)$ is sufficiently large, the marginal productivity of labor is increasing function to labor supply.

\section{Conclusion}

This paper induces the condition of resolving the "Fiscal Policy Puzzle” using static general equilibrium model with human capital which increases by on-the-job training. In the benchmark model of Barro and King (1984), government spending is merely wasteful and causes a negative wealth effect, which decreases private consumption and increases labor supply, which decreases real wage as a result. Although there are a lot of formations of human capital accumulation, we assume that labor supply accumulates human capital as on-the-job training. We obtain the results that the expanding government spending increases private consumption and real wage if the human capital externality is sufficiently large.

\section{References}

[1] Barro, R. and King, R. (1984) Time Separable Preferences and Intertemporal Substitution Models of the Business 
Cycle. Quarterly Journal of Economics, 99, 817-840. http://dx.doi.org/10.2307/1883127

[2] Baxter, M. and King, R. (1993) Fiscal Policy in General Equilibrium. American Economic Review, 83, 315-334.

[3] Fatás, A. and Mihov, I. (2001) The Effects of Fiscal Policy on Consumption and Employment: Theory and Evidence. INSEAD.

[4] Blanchard, O. and Perotti, R. (2002) An Empirical Characterization of the Dynamic Effects of Changes in Government Spending and Taxes on Output. Quarterly Journal of Economics, 117.

[5] Galí, J., López-Salido, J. and Vallés, J. (2007) Understanding the Government Spending on Consumption. Journal of the European Economic Association, 5, 227-270. http://dx.doi.org/10.1162/JEEA.2007.5.1.227

[6] Becker, G. (2009) Human Capital: A Theoretical and Empirical Analysis, with Special Reference to Education. 3rd Edition, University of Chicago Press, Chicago. 
Scientific Research Publishing (SCIRP) is one of the largest Open Access journal publishers. It is currently publishing more than 200 open access, online, peer-reviewed journals covering a wide range of academic disciplines. SCIRP serves the worldwide academic communities and contributes to the progress and application of science with its publication.

Other selected journals from SCIRP are listed as below. Submit your manuscript to us via either submit@scirp.org or Online Submission Portal.
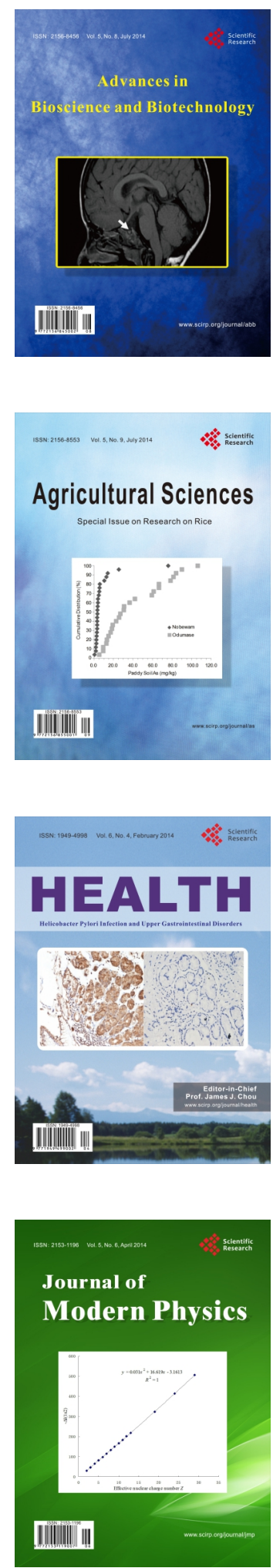
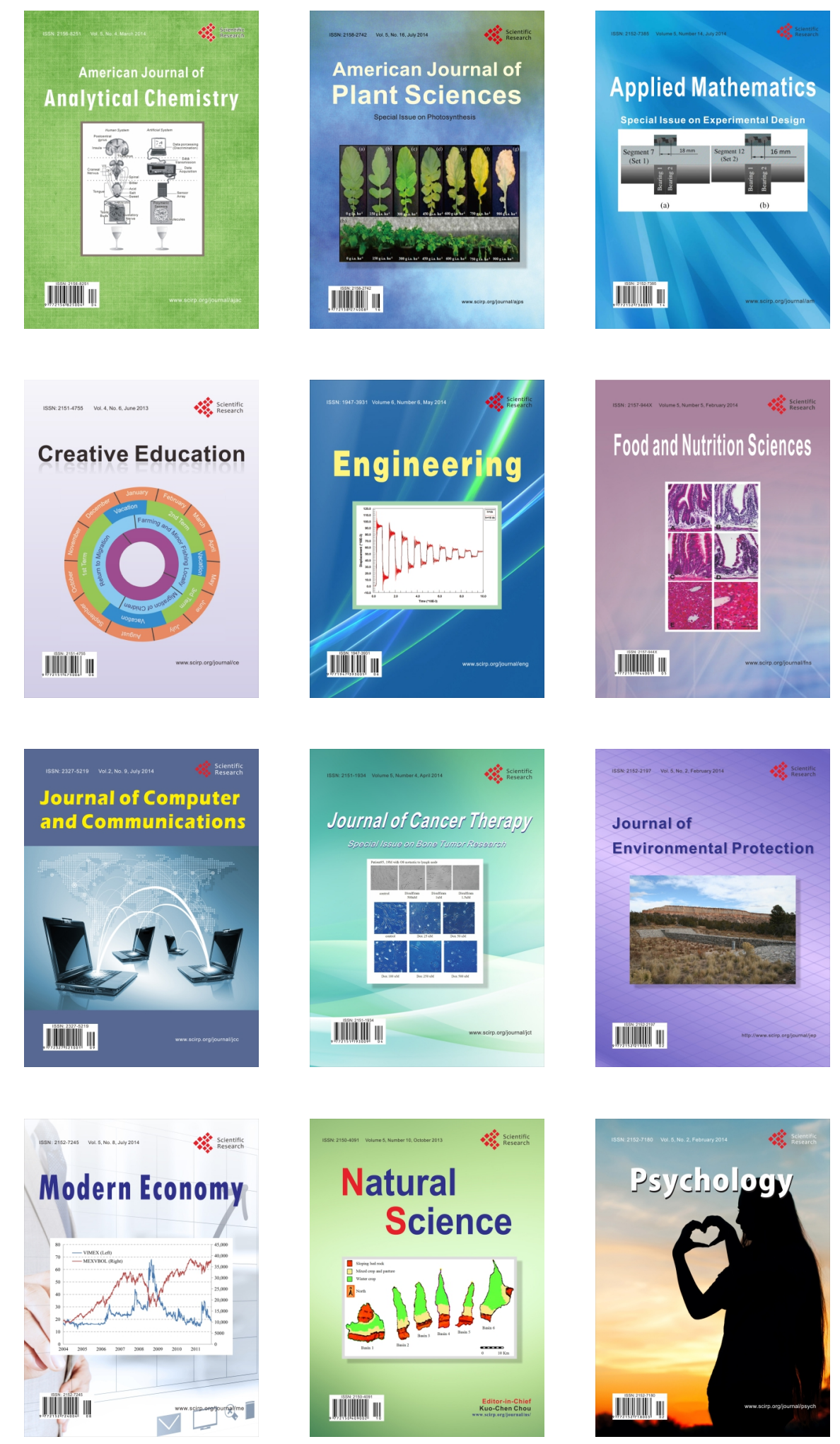